\title{
Lahoratorul de Botanică-Dendrologie sau despre începuturile Facultății de Silvicultură din Suceava
}

\author{
CI. Horeanu, G.V. Tomescu, F. Clinouschi
}

Horeanu Cl., Tomescu, C.V., Clinovschi F., 2020. The Botany-Dendrology Laboratory or about the beginnings of the Faculty of Forestry from Suceava. Bucov. For. 20(1): 83-87.

Abstract. The Botany-Dendrology Laboratory has been one of the reference laboratories in which the future forestry engineers, trained at the Faculty of Forestry in Suceava, get in touch with the respective higher education. Equipped with teaching materials and devices corresponding to the disciplines for which the room was intended, with the support, participation and involvement characteristic of any beginning, Professor Climent Horeanu and his disciples, Florin Clinovschi and Cezar Valentin Tomescu managed to give life to it and to demonstrate that a simple laboratory can acquire polyvalent dimensions, both formative-educational and social.

Starting from a microscope found by chance at the University of Suceava and from a generous package of pressed plants, gathered with hard work and passion, for a quarter of a century, by Professor Horeanu, the laboratory dedicated to the fields of Botany and Dendrology also \&quot; welcomed\&quot; a discipline similar to the previous two, Landscape Architecture and Forest Design. Today the laboratory has a special dendrological and arboreal ornamental collection in Campus 1 of the University of Suceava, to which is added a large area in Campus 2, where a botanical garden and a dendrological park are coming to life.

Keywords: scientific research, Faculty of Forestry, Suceava.

Authors. Climent Horeanu, Cezar Valentin Tomescu (cezar.tomescu@usm.ro), Florin Clinovschi - Ștefan cel Mare University of Suceava, Forestry Faculty, 13 Universității, 720229 Suceava, Romania.

Manuscript received August 14, 2020; revised August 18, 2020; accepted August 18, 2020; online first August 20, 2020.

\section{Cum am Iuat ființă...}

Martie 1990 a însemnat crearea Universității „Ștefan cel Mare” din Suceava și, odată cu ea, a apărut și Facultatea de Silvicultură. Această apariție a fost considerată o mare provocare pentru învățământul forestier superior din România, pentru că tradiționalei Facultăți de Silvicultură și Exploatări Forestiere din Brașov i se alăturase o instituție silmilară care se dorea a fi continuatoarea Facultății de Silvicultură de la Câmpulung Moldovenesc.

Și, ca orice început, nu a fost ușor... Erau multe necunoscute și incertitudini, dar era ceva care umplea orice gol: energia, motivația și entuziasmul unui nou început! Deși dosarul de înființare al facultății era complet, la începutul anului universitar s-a constatat că lipseau 
multe: spatiiile erau insuficiente, nu erau destule cadre didactice cu experiență în învăţământul universitar, iar baza materială necesară unei facultăți de silvicultură era, practic, inexistentă. Totuși, prin eforturi, cu mult curaj și dăruire, la 1 octombrie 1990, s-a deschis anul universitar pentru învățământul superior silvic sucevean, cu o echipă proprie de cadre didactice formată din cinci temerari: profesor Ioan Milescu, conferenţiar Climent Horeanu, asistenţii Ovidiu Iacobescu şi Valerian Marocico, precum și preparator Ancuța Tăbăcaru.

Aceștia au dus greul acelui început, rânduind toate cele pentru ca prima promoție de ingineri silvici formaţi de universitatea suceveană (50 studenţi români şi 25 din Republica Moldova) să beneficieze de un proces de învățământ performant, susținut de oameni cu ținută academică.

\section{Laboratorul de Botanică-Dendrologie: renumita S21}

Postul de titular al disciplinelor Botanică, ulterior şi Dendrologie, a fost ocupat de profesorul Climent Horeanu, doctor în biologie vegetală, cadru universitar venit de la Facultatea de Biologie din Iași. La început de drum, maturitatea şi experienţa domniei sale și-au spus cuvântul, pentru că fusese format de mari profesori de biologie ai Universităţii „Al. I. Cuza” din Iași, făcuse parte din aparatul administrativ al Academiei Române - Filiala Iași și fusese unul dintre inițiatorii unei viitoare Grădini Botanice din Agigea-Constanța ${ }^{1}$, în staţiunea de la malul mării care aparținea universității ieșene.

Facultăţii de Silvicultură i-au fost repartizate o încăpere pentru birourile celor cinci cadre didactice titulare şi două săli pentru laboratoare. Cea mai mare, sala S21 din corpul A al universității, a fost amenajată ca Laborator de botanică, iar din anul următor și ca Laborator de

1) În anul 1975, în contextul construcției Canalului Dunăre - Marea Neagră, activitățile de cercetare, de învățământ universitar și instalarea noii grădini botanice la care lucra domnul profesor Climent Horeanu au fost sistate și abandonate.

84 dendrologie. Întrucât cele două discipline constituie abecedarul oricărui silvicultor, profesorul Horeanu le-a conferit importanța cuvenită, depunând eforturi deosebite pentru a dota sala S21 cu material didactic și aparatura necesară. După cum domnia sa a afirmat în multe rânduri, studenții nu trebuiau să simtă că facultatea se afla la început de drum şi că nu era deloc ușor să asigure fluența activităților didactice.

Planul de învățământ al viitorilor ingineri silvici conţinea, în anul I, printre multe alte discipline, Botanica, derulată pe parcursul a două semestre, iar în anul II Dendrologia tot pe parcursul a două semestre. În acest context, profesorul Horeanu, împreună cu tânăra asistentă universitară Anca Tăbăcaru (căs. Lucău-Dănilă) au reușit să utileze sala S21 cu tot ce era necesar.

Dotarea laboratorului a pornit de la un microscop IOR găsit prin universitate. Ulterior s-au mai cumpărat încă 10 microscoape IOR şi un microscop ML4. Pentru Dendrologie s-au cumpărat 12 lupe binoculare din stocurile lichidate de IOR București.

Între anii 1990-1992, concomitent cu pregătirea cursurilor de Botanică și Dendrologie, profesorul Horeanu s-a preocupat să pună la dispoziția studenților materialul didactic necesar lucrărilor practice aferente celor două discipline:

- ierbare cu plante colectate chiar de către dumnealui aproape din toate zonele țării vreme de 23 ani, încă din 1967, de la absolvirea a Facultăţii de Biologie²,

- material proaspăt (ramuri, frunze, fructe, semințe ale speciilor lemnoase),

- plante din covorul ierbaceu al diverselor etaje fitoclimatice,

- preparate microscopice permanente,

- mici cantităţi de substanțe de colorare şi fixare,

- substanțe necesare pentru preparate provizorii.

De precizat că sala S21 fusese, înainte de 1989, cabinet de stiinţe sociale, fiind ,dotată”

$\left.{ }^{2}\right)$ Materialele colectate de către profesorul Horeanu se găsesc și astăzi în arhiva Laboratorului de Botanică-Dendrologie 


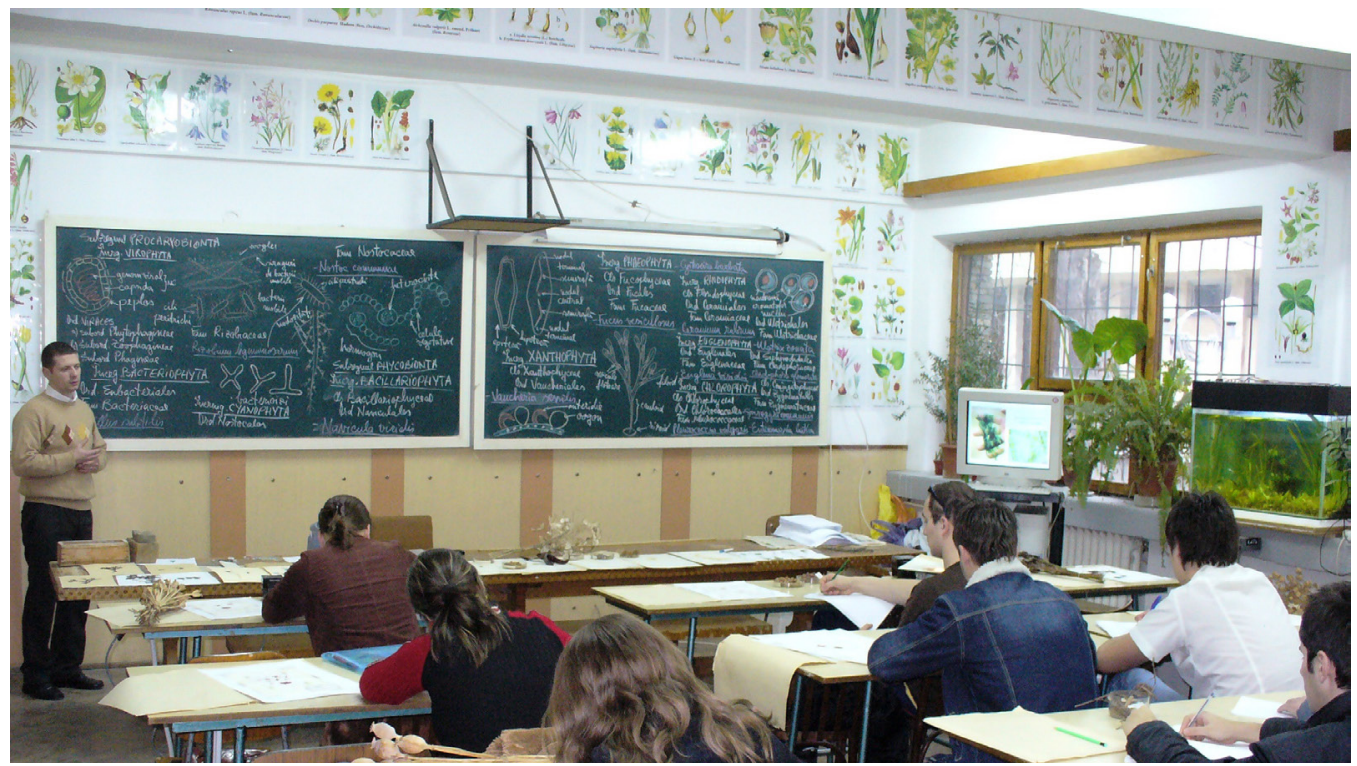

cu o serie de vitrine fixate pe un întreg perete. Acest perete-vitrină a servit pentru amenajarea unei colecţii de seminţe, fructe, conuri, lujeri şi rondele (toate etichetate), devenind astfel frontispiciul laboratorului de Botanică-Dendrologie, pe care studenții primei promoții îl urmăreau săptămână de săptămână, din curiozitate, ca să vadă ce a mai ,,apărut” nou. Şi profesorul Horeanu știa acest lucru, astfel că avea grijă să aducă ,noutăți” pentru studenții curioși și doritori de carte. Procedând în acest mod, secondat de asistenţii domniei sale, în câţiva ani aceste vitrine au devenit neîncăpătoare, iar pereții laboratorului au fost „,tapetaţi” cu planșe cu material presat al unor specii de plante deosebite.

Pentru a facilita învățarea speciilor lemnoase, s-a asigurat un bogat material dendrologic (ramuri cu frunze, flori, seminţe, fructe, lujeri, scoarţă, rondele). Organizarea laboratorului dispunea astfel de toate materialele silvobiologice care să asigure o pregătire corespunzătoare a studentililor.

De ce renumita sală $S 21$ ?

Pentru că această sală S21 a fost centrul activităţilor didactice pentru numeroase promoții de studenți şi a ,văzut” toate evenimentele importante ale Facultății de Silvicultură din Suceava de la înființare și până în 2008, când facultatea a primit alte spații în noul corp E al universității sucevene. Când nu erau ore de lucrări practice la Botanică sau Dendrologie, în sala S21 se organizau ședințe de catedră, se susțineau referate și teze de doctorat, concursuri, se desfășurau examenele de licență, se corectau teze de la examenele de admitere.

Totodată, pentru a rememora și câteva aspecte ale vieții sociale din Facultatea de Silvicultură, în sala S21 se primeau studenții cu colinda, se ciocnea un pahar cu şampanie după cursurile festive sau în zilele de sărbătoare ale facultății.

\section{Un alt fel de lucrări practice...}

Din dorința de a arăta că pădurea și plantele se simt cu adevărat când sunt văzute în mediul lor, cadrele care au deservit disciplinele Botanică şi Dendrologie, au conceput și organizat ieșiri ale studenților în teren. Chiar din primul an de existență a facultăţii, profesorul Horeanu a dovedit că spațiile verzi din oraş reprezintă un adevărat laborator viu, iar entuziasmul ge- 
neral a încurajat deplasări ulterioare în Munții Rarău, precum și alte excursii tematice în județele Suceava, Neamţ, Bacău, Botoșani, Iași, Bistrița-Năsăud, Mureș.

$\mathrm{Cu}$ sprijinul organelor silvice s-au organizat practicile de sfârșit de an: vreme de 7-8 zile, studenții au văzut şi analizat tematic pădurile montane de pe Rarău, Giumalău, Valea Bistriței, Călimani, Rodna, turbăria Grădinița, Rezervațiile Codrul multisecular Slătioara, Tinovul Mare Poiana Stampei, Lala, Zamostea-Luncă, Ciornohal (BT), Mociar (MS), dar și multe alte păduri din zonele de deal, câmpie sau de silvostepă.

Acest mod de predare a celor două discipline a devenit cutumiar, iar ieșirile în teren au devenit treptat cvasi-permanente.

\section{Propria grădina hotanică și colecție dendrologică}

Prin mobilizarea studenţilor din primele promoții, s-a realizat o mică colecție dendrologică în spaţiul verde al Universității, aducând material de la Grădina Botanică din Iași, Parcul Dendrologic Hemeiuş, din diferite zone ale pădurilor de silvostepă sau din zona montană. Construcțiile ulterioare, diverse lucrări de la rețelele de apă, canalizare şi termoficare au afectat aproape în totalitate materialul dendrologic aflat în plină dezvoltare.

Ulterior, cu sprijinul reprezentanților Ocolului Silvic Adâncata și Direcției Silvice Suceava, pe un teren din imediata proximitate a sediului Ocolului Silvic Adâncata s-a încercat să se realizeze o colecție dendrologică. S-a plantat, cu studenții, un bogat material dendrologic adus din Parcul Dendrologic Simeria. Schimbările conjuncturale au afectat, parțial, colecția, chiar din anul care a urmat plantării; totuşi, încă se mai păstrează numeroase specii lemnoase interesante.

Realizarea de construcții pentru celelalte facultăți, precum şi modernizarea întregului campus în ultimii ani, au permis o reamenajare a spaţiului verde din campusul universităţii, introducându-se numeroase specii lemnoase 86 exotice ornamentale (specii de magnolii, arborele lalea, oțetar roșu, cireș japonez, diverse rășinoase etc.) de către Cezar Tomescu.

Finalizarea corpului E al universității sucevene a avut loc în anul 2008, moment în care Facultatea de Silvicultură s-a mutat şi s-a reorganizat în spaţiul repartizat, beneficiind de mai multe laboratoare, săli de cursuri sau seminarii, precum şi de birouri, necesare activităţilor de învăţământ și cercetare. Botanica şi Dendrologia asociate cu Arhitectura Peisageră și Proiectarea Spațiilor Verzi au primit o sală pentru desfăşurarea lucrărilor practice şi o mică încăpere pentru biroul celor trei cadre didactice care predau disciplinele sus amintite. Din vechea sală S21 s-a mutat tot ce s-a putut recupera, iar apoi s-a completat cu alte materiale.

Obținerea de către Universitatea, ,Ştefan cel Mare" a unei suprafeţe de 30 ha pentru încă un campus studențesc, a reprezentat un câștig care va fi transformat într-un avantaj al Facultații de Silvicultură, deocamdată puțin vizibil. În Campusul 2 al USV se doreşte construirea mai multor clădiri, dintre care una va fi alocată Facultăţii de Silvicultură. Senatul Universităţii a hotărât ca, în acest campus, să se organizeze şi o grădină botanică, care să includă obligatoriu o colecţie dendrologică. Proiectul a fost întocmit de un colectiv de specialiști din cadrul Universităţii de Arhitectură şi Urbanism „Ion Mincu”, Bucureşti, în baza temei de proiectare propuse de conducerea USV. Treptat s-au delimitat pe teren diferitele sectoare fitogeografice, iar în perioada 2016-2020 s-au plantat unele specii caracteristice acestora.

\section{La început, cu gândul spre viitor...}

Rigoarea universitară impusă de cadrele didactice care predau disciplinele Botanică şi Dendrologie, modul de lucru cu studenții, dotarea laboratorului, frecventele ieșiri în teren au dus la definirea ansamblului disciplină-profesor-laborator ca referință la nivel de facultate. Comisiile de evaluare ARACIS (fost CNEAA) 
care au vizitat facultatea pentru acreditarea programelor de studiu Silvicultură au apreciat eforturile făcute pentru a pune la dispoziția studenților un laborator atât de expresiv.

În anul 1995, din prima promoție a Facultăţii de Silvicultură din Suceava s-au selectat şase absolvenți pentru a rămâne în facultate, în calitate de cadre didactice. Astfel, dintre aceștia, Florin Clinovschi a fost angajat în primă etapă ca preparator pentru a preda orele de lucrări practice la disciplina Dendrologie, iar astăzi este conferențiar, titular al disciplinei preluate de la magistrul lui, profesorul Horeanu.

Din a doua promoție a fost selectat Cezar Valentin Tomescu, care predă, din anul 1996, orele de lucrări practice aferente Botanicii, iar din anul 2010 susține și orele de curs.

Profesorul Horeanu, în calitate de titular al celor două discipline a elaborat, multiplicat şi pus la dispoziția studenților cursurile de Botanică şi Dendrologie, utilizate ulterior şi de către studenții ID (învăţământ la distanţă). Aceste cursuri, bine documentate, au constituit principala motivație pentru discipolii profesorului, de a elabora și actualiza cu propria lor amprentă conținuturile științifice ale cursurilor universitare pentru disciplinele Botanică și Dendrologie.

Pe parcursul celor 30 de ani de existență a Facultății de Silvicultură, studenții au beneficiat de o pregătire care a permis acumularea de cunoştințe solide pentru profesia de inginer silvic, iar cadrele didactice titulare, provenite îndeosebi din rândul absolvenților, dar și cele asociate (din Brașov, Câmpulung Moldovenesc, Iaşi, Bucureşti) şi-au dat tot concursul pentru a contribui la reușita pe care o vedeau în perspectivă cei cinci temerari în 1990 . 